\title{
Strategi Komunikasi Politik Juru Bicara Wakil Presiden Jusuf Kalla (JK) 2014-2019 sebagai Humas Pemerintah
}

\author{
Silvanus Alvin \\ Universitas Bunda Mulia \\ E-mail: silvanusalvin@gmail.com
}

DOI: https://doi.org/10.21107/ilkom.v14i1.6031

\begin{abstract}
ABSTRAK
Keberadaan Government Public Relations itu penting di tengah tuntutan keterbukaan informasi. Meski demikian, penelitian yang membahas topik ini di lingkup istana masih minim. Berangkat dari keresahan tersebut penelitian ini dilakukan untuk mengungkap strategi yang diterapkan oleh Juru Bicara Wakil Presiden periode 2014-2019 sebagai humas pemerintah. Metode yang dipakai dalam penelitian kualitatif ini adalah wawancara mendalam serta observasi terhadap Husain Abdullah selaku Juru Bicara Wakil Presiden 20142019. Terdapat beberapa tahapan-tahapan strategi yang diterapkan, yakni penentuan citra pihak yang direpresentasikan, penentuan publik sasaran, menjalankan fungsi manajemen komunikasi dan fungsi proteksi, serta evaluasi. Selain itu, temuan menarik dari penelitian ini membuktikan Husain Abdullah sebagai Juru Bicara Wakil Presiden 2014-2019 diberikan keleluasaan dalam menentukan strategi komunikasi politik yang ia rasa penting dilakukan, tanpa perlu melapor ataupun mendapat persetujuan dari Jusuf Kalla sebagai pihak yang direpresentasikan. Beberapa bentuk keleluasaan itu antara lain adalah kebebasan dalam menginterpretasikan pesan wakil presiden kemudian menyebarluaskan kepada pers, berperan pula sebagai penasihat (advisor) yang bisa memberi masukan-masukan, serta menentukan konten-konten mana yang layak di media sosial tanpa perlu persetujuan Jusuf Kalla.
\end{abstract}

Kata kunci: juru bicara, wakil presiden, jusuf kalla, komunikasi politik, dan government public.

\begin{abstract}
The existence of government public relations is important in the midst of demands for information disclosure. Nevertheless, research on this topic, especially the practice within the vice-presidential palace is still minimal. This research was conducted to uncover the political communication strategy adopted by the Vice President's Spokesperson for the 2014-2019 period as the government public relations. The method used in this qualitative study was in-depth interviews and observations on Husain Abdullah who appointed as the Vice President's Spokesperson 2014-2019. There are several stages of the political communication strategy implemented, namely determining the image of the person who was represented, determining the spesific public, carrying out the communication management and protection functions against crisis, and performing evaluation. In addition, one interesting finding from this study is the freedom that Husain Abdullah earned from the Vice President Jusuf Kalla to determine the political communication strategy that he felt was important, without reporting or obtaining approval from Jusuf Kalla as the party represented. Some forms of discretion include the freedom to interpret the vice president's message and then disseminate to the press. Husain also entitled to act as an advisors who can provide input, and determine which content is appropriate to be posted on social media without the need for Jusuf Kalla's approval.
\end{abstract}

Keywords : spokesperson, vice president, jusuf kalla, political communication, and government public relations 


\section{PENDAHULUAN}

Praktik public relations (PR) dibutuhkan manakala seorang individu maupun organisasi berusaha untuk menciptakan maupun mempertahankan reputasi serta citra yang baik (Butterick, 2014). Setiap ada ketersinggungan dengan publik, di situ dibutuhkan peran PR. Kegiatan PR tidak terbatas hanya untuk organisasi atau perusahaan yang bergerak di dunia bisnis, yang tujuan utamanya hanya mengejar profit semata, melainkan juga perlu dilakukan oleh pemerintah. Djusan (2012), Butterick (2014), dan Suprawoto (2018) menegaskan keberadaan PR dalam pemerintahan adalah mutlak.

Pentingnya PR dalam pemerintah pula yang mendasari lahirnya government public relations (GPR). Suprawoto (2018) menjelaskan PR pemerintah merupakan 'fungsi komunikasi yang menghubungkan interaksi warga dengan pemerintah, dengan regulator, dan perpanjangan tangan kebijakan pemerintah' (hlm. 49).

Pasca-reformasi telah menempatkan Indonesia dalam babak baru dari segala sisi, terutama di bidang komunikasi. Bila sebelum reformasi, pemerintah hanya menerapkan komunikasi satu arah (Djusan, 2012), maka sekarang pemerintah perlu melakukan komunikasi dua arah. Djusan (2012) menjelaskan pemerintah wajib menyampaikan informasi tentang kebijakankebijakannya dan juga perlu mendengar serta menyerap aspirasi dari masyarakat. Apalagi, hal tersebut diperkuat juga oleh UndangUndang Nomor 14 Tahun 2008 tentang Keterbukaan Informasi Publik (KIP).

UU KIP itu yang menjadi dasar yang membedakan praktik PR secara umum dengan PR pemerintah. Suprawoto (2018) menjelaskan PR secara umum hanya berurusan dengan publik yang tersegmentasi atau stakeholder sesuai dengan kebutuhan organisasi, sementara praktik PR pemerintah melayani seluruh warga negara. Selain itu, masih menurut Suprawoto (2018) PR pemerintah tidak berurusan dengan kegiatan komunikasi yang mendatangkan profit secara finansial, karena keberadaan PR pemerintah guna memenuhi hak masyarakat dalam mendapatkan akses informasi serta komunikasi.

Penyampaian informasi kepada masyarakat dan juga penyerapan informasi masyarakat tidak boleh dilakukan secara sembarangan. Sebab, hal tersebut dapat memberikan imej yang buruk terhadap pemerintah. Apabila mendapat imej buruk, bukan tidak mungkin pemerintah itu kehilangan legitimasinya atau kepercayaan dari masyarkat. Budiardjo (2008) mengatakan sebuah pemerintahan bisa langgeng jika menggabungkan kewenangan formal serta legitimasi.

Wakil presiden, dalam ranah eksekutif, termasuk sebagai perwujudan dari pemerintah. Mandat serta beban kerja seorang Wakil Presiden Republik Indonesia diatur dalam Undang-Undang Dasar (UUD) 1945 di dalam Pasal 4 ayat 1 dan 2, Pasal 6 ayat 2, Pasal 7, Pasal 8, dan Pasal 9. Maksum (2015) menjelaskan secara garis besar ada empat tugas utama dari seorang wakil presiden. Pertama, membantu presiden dalam memimpin negara. Kedua, menjadi pengganti presiden bila presiden berhalangan ataupun meninggal dunia. Ketiga, menyerap aspirasi masyarakat, mendalami, dan menindaklanjuti masalah-masalah kesejahteraan rakyat. Keempat, membantu presiden dalam hal pengawasaan terhadap lembaga-lembaga pemerintahan di bawahnya agar menjalankan tugas dan fungsi yang semestinya.

Dalam ranah komunikasi politik, wakil presiden sebagai komunikator polik perlu mengkomunikasikan pesan-pesan politiknya dengan tepat kepada masyarakat. Bila pesan-pesan politik tidak disampaikan dengan baik, maka bisa saja wakil presiden kehilangan kepercayaan dari masyarakat. Implikasi dari turunnya kepercayaan publik tentu bisa berefek pada melemahnya kepercayaan terhadap pemerintah secara menyeluruh (Budiardjo, 2008; Butterick, 2014; Suprawoto, 2018). Untuk itu, wakil 
presiden membutuhkan bantuan praktisi PR demi menjaga komunikasi politik terhadap masyarakat terlaksana dengan baik dan benar.

Muhammad Jusuf Kalla (JK) telah menjabat sebagai Wakil Presiden Republik Indonesia untuk dua periode berbeda, di era Presiden Susilo Bambang Yudhoyono, pada 2004-2009 dan Presiden Joko Widodo, pada 2014-2019 (Hasjanah, 2019). Dalam dua kurun waktu yang berbeda itu, JK memiliki sebuah tim PR, yang dikepalai oleh Husain Abdullah (Kambie, 2016; Setyawan, 2016).

Di lingkungan istana, jabatan resmi yang diemban oleh Husain adalah Staf Khusus Wakil Presideng Bidang Komunikasi dan Informasi atau biasanya dikenal sebagai Juru Bicara Wakil Presiden (WapresRI, 2017). Sebelum memulai karir sebagai seorang juru bicara, Husain memulai karirnya sebagai seorang wartawan dari salah satu stasiun televisi swasta, yaitu RCTI (Darmawan, 2016). Posisi sebagai Juru Bicara Wakil Presiden Republik Indonesia mengharuskan Husain Abdullah menjadi 'jembatan' antara Wakil Presiden Jusuf Kalla dan media atau pers, serta masyarakat. Sebab, beban kerja wakil presiden tidak memungkinkan JK untuk bisa meladeni beragam pertanyaan dari wartawan maupun publik tiap saat.

Bagi McNair (2011), juru bicara adalah pria atau wanita yang memiliki kompetensi untuk menjadi perwakilan seorang aktor politik maupun organisasi politik dan memiliki wewenang untuk berbicara. Lebih lanjut, jabatan juru bicara di lingkungan istana merupakan posisi yang sulit. Sebab, menurut Seitel (2015), seorang juru bicara tidak hanya sekadar penyambung lidah, melainkan ia juga harus mempercayai keputusan yang diambil oleh pimpinannya itu.

Penelitian maupun studi literatur terkait dengan praktik dan strategi komunikasi juru bicara dalam ranah government public relations di lingkungan istana masih minim. Sejauh ini, beragam penelitian terkait PR pemerintah lebih banyak berfokus pada strategi-strategi komunikasi di sebuah pemerintahan daerah. Beberapa di antaranya adalah penelitian Kadir (2009) yang membahas pentingnya peran PR pemerintah dalam mencitrakan Kota Malang sebagai kota edukasi, penelitian Ristanto (2014) yang menyarankan peran serta PR Kota Balikpapan dalam mengimplementasikan konsep smartcity atau kota pintar, dan penelitian Herlina (2015) yang kembali membahas pentingnya keberadaan humas pemerintah bagi Kota Malang. Penelitian ini menjadi penting karena membedah secara mendalam dan membahas strategi komunikasi politik seorang juru bicara yang berada di dalam lingkungan istana.

Pemerintah perlu membangun dan menjaga citra dirinya yang positif, agar pemerintahannya dapat berjalan dengan baik. Hal tersebut dapat dipenuhi bila terjadi komunikasi yang baik antara pemerintah dan masyrakatnya. Implikasinya, akan ada pemahaman yang berujung pada dukungan dari masyarakat terhadap pemerintah. Lebih lanjut, beban kerja pejabat eksekutif akan berlebihan bila terus menerus berhubungan dengan masyarakat, maka dari itu diperlukan peran juru bicara.

Namun, minimnya penelitian terkait dengan juru bicara dalam ranah PR pemerintah di lingkungan istana menandakan kurangnya informasi yang valid secara akademis untuk menunjang hal tersebut. Oleh karena itu, penelitian ini perlu dilaksanakan dalam menunjang pemahaman akademis terkait dengan strategi komunikasi juru bicara, terutama di lingkungan istana. Selain itu, pemaparan dari penelitian ini juga dapat dimanfaatkan dalam praktik nyata.

Penelitian-penelitian yang ada belum membahas praktik kerja juru bicara di dalam ring satu pemerintahan secara spesifik sebagai objek penelitian. Berangkat dari fakta-fakta dan penjelasan di atas, maka peneliti merumuskan pertanyaan penelitian, yakni Bagaimana strategi komunikasi yang diterapkan Juru Bicara Wakil Presiden sebagai Humas Pemerintah? 


\section{Strategi Komunikasi Politik}

McNair (2011) menegaskan bahwa setiap komunikasi yang dilakukan oleh seorang aktor politik maupun organisasi politik pastilah memiliki intensi politik tertentu yang berusaha dicapai. Thompson (2001) seperti dikutip oleh Rachmiatie dkk (2013, hlm. 125-126) menjelaskan lima poin utama dalam membuat strategi komunikasi politik, yakni sebagai berikut.

1. Menetapkan visi individu maupun organisasi

2. Merancang rencana yang mengacu pada visi maupun misi, dan ditunjang oleh data serta informasi

3. Menentukan taktik atau langkah-langkah praktis, dengan memperhitungkan kemampuan internal dan kondisi lingkungan

4. Menempatkan posisi individu atau organisasi sesuai dengan hal yang ingin dicapai

5. Menyusun pola aktivitas komunikasi agar dapat dijalankan secara taktis oleh pelaku komunikasi

Lebih lanjut, McNair (2011) juga menuliskan bahwa tujuan dari penerapan strategi komunikasi politik ialah kesepahaman manufaktur (the manufacture of consent). Para aktor politik ketika melakukan aktivitas komunikasi, melakukan seleksi lebih dulu atas informasi apa saja yang akan mereka bagikan pada audiensnya. Seleksi atas informasi sebenarnya sah-sah saja dilakukan, karena bisa saja ada sebuah informasi yang memang berkaitan dengan keamanan nasional (national security). Bila informasi itu bocor maka dikhawatirkan akan mengancam sebuah negara. Di lingkungan istana, wajar ada begitu banyak informasi yang masuk dalam kategori tersebut, sehingga tidak semua informasi harus diketahui publik.

Meski demikian, McNair (2011) menggarisbawahi bahwa seleksi yang terlalu ketat atas informasi-informasi dapat mengarahkan aktor politik untuk melakukan manipulasi dan tipuan (manipulation and deception).

\section{PR Pemerintah (Government Public Relations)}

Terdapat beragam definisi terkait Public relations (PR). Peneliti akan menjabarkan lebih dulu beberapa definisi yang lazim digunakan untuk memahami konsep tentang PR. Public Relations Society of America (PRSA, 2019) melihat PR sebagai strategi komunikasi yang membangun kesepahaman mutual antara organisasi dan publik tujuannya. Sementara, Soemirat dan Ardianto (2017) menuliskan definisi dari PR sebagai usaha terus menerus secara sadar untuk mempengaruhi publik melalui komunikasi, agar timbul rasa hormat terhadap individu maupun organisasi supaya dapat bertahan dalam menghadapi cobaan dan tantangan. Di sisi lain, Chatered Institute of Public Relations (CIPR) dalam Butterick (2014) menjelaskan PR secara sederhana adalah manajemen reputasi.

Lee, Neely, dan Stewart (2012) menilai praktik PR tidak hanya berlaku bagi dunia swasta saja, melainkan juga praktik tersebut juga harus diterapkan oleh pemerintah. Di dalam PR, elemen utamanya adalah komunikasi dua arah. Di era saat ini, pemerintah tidak bisa hanya melakukan komunikasi satu arah atau sekadar berperan sebagai produsen pesan. Sebab, Butterick (2014) menuliskan 'pemerintah juga merupakan sasaran dari komunikasi dan persuasi' (hlm. 192). Oleh karena itu lahirlah konsep serta praktik dari PR pemerintah.

Menurut Kementerian Komunikasi dan Informatika (2016) PR pemerintah adalah 'pengelolaan informasi dan komunikasi yang berkelanjutan untuk memperoleh pemahaman dan dukungan terhadap program dan kebijakan pemerintah'. Selain itu, Suprawoto (2018) memaparkan bahwa PR pemerintah sebagai fungsi manajemen komunikasi dari sebuah pemerintahan yang tanggap serta membina hubungan timbal balik dengan warga negaranya. Sementara, Arofi (2018) 
menuliskan bahwa PR pemerintah merupakan aktivitas komunikasi yang dapat menjembatani warga dengan pemerintah dan sebaliknya.

Kata kunci yang esensial dalam penjelasan atas PR pemerintah adalah adanya aktivitas timbal balik. Hal ini berarti, pemerintah tidak hanya membuat dan menyebarkan pesan saja, melainkan juga menyerap aspirasi dari publik. Ditambahkan Suprawoto (2018) bahwa dalam sebuah pemerintahan yang menerapkan sistem demokrasi, komunikasi dua arah dengan masyarakatnya bisa menambah akuntabilitas dan memberikan dampak positif berupa dukungan terhadap pemerintah.

Arofi (2018) dan Suprawoto (2018) sepakat bahwa terdapat tiga perbedaan mendasar antara pelaksaan PR pada umumnya dan PR pemerintah. Pertama, PR pemerintah tidak berorientasi untuk mendatangkan profit finansial atau tidak komersil karena pemerintah tidak menjual produk atau jasa tertentu. Kedua, praktik PR pemerintah merupakan bagian dari pemenuhan hak-hak warga negara, sementara PR pada umumnya hanya akan mengurus publik sesuai target tujuan mereka. Ketiga, posisi PR pemerintah berada di dalam lingkup eksekutif, berbeda dengan PR pada umumnya yang berada di sektor swasta.

Lebih lanjut, Lee, Neely, dan Stewart (2012) menjabarkan tiga tugas utama dari PR pemerintah, yakni sebagai berikut.

1. Membangun hubungan dengan media (media relations): terdapat hubungan cinta sekaligus benci antara PR dan wartawan dari berbagai media. Di satu sisi, PR membutuhkan media untuk publikasi dan penyampaian informasinya kepada publik. Di sisi lain, PR harus berhadapan dengan kegigihan media manakala ada isu miring atau krisis yang menimpa pemerintah. Konsep ini secara khusus akan dijabarkan pada bagian di bawah ini.

2. Laporan kepada publik (public reporting): melaporkan setiap kegiatan pemerintah kepada masyarakat sebagai wujud keterbukaan informasi melalui beragam bentuk media, baik media cetak, media elektronik (televisi dan radio), media internet (laman web dan media sosial).

3. Tanggung jawab pada masyarakat (responsiveness to public as citizens): tanggung jawab terhadap masyarakat merupakan hal utama bagi pemerintah. Sebab, pemangku kepentingan bagi pemerintah tidak bersifat satu dimensi, seperti klien atau investor potensial, melainkan seluruh warga negara dari sebuah pemerintahan.

\section{Media Relations}

Media relations dapat dipahami sebagai salah satu kegiatan yang dilakukan praktisi PR dengan cara membangun hubungan baik dengan para jurnalis dari berbagai media (Triyono, 2013; Nurjanah, Widyasari, dan Yulianti, 2015). Lebih lanjut, terdapat hubungan simbiosis mutualisme antara PR dan jurnalis. Secara umum, kerja jurnalis selalu bergelut dengan batas waktu tayang maupun jadwal produksi yang ketat. Di saat yang bersamaan, PR datang memberikan materi maupun informasi yang dapat diolah para jurnalis menjadi berita. Tindakan praktisi PR dalam membantu jurnalis dikenal sebagai konsep media relations.

Sementara, Raharjo (2015) menjelaskan ada tiga tujuan dari media relations. Pertama, meningkatkan kesadaran dan pemahaman publik melalui publikasi. Kedua, mengubah sikap publik. Ketiga, mendorong tindakan yang mendukung pihak yang ditangani oleh PR.

Para praktisi PR biasanya melaksanakan dua tugas utama dalam media relations dengan menerapkan subsidi informasi (information subsidy). Park, Bier, dan Palenchar (2016) menuliskan ada dua jenis subsidi informasi. Jenis pertama yaitu, subsidi informasi yang proaktif, yaitu PR secara aktif membagikan informasi kepada para jurnalis, salah satunya dengan cara menggelar konferensi pers atau menyebar siaran pers. Jenis kedua yaitu, subsidi informasi yang 
reaktif. Dalam jenis tersebut, pihak yang aktif berasal dari para jurnalisnya dengan cara melontarkan beragam pertanyaan dan PR memberikan informasi dengan menjawab pertanyaan-pertanyaan itu.

Olga (2014) mengkritisi bahwa dalam praktik subsidi informasi, PR memiliki kontrol minim dan bahkan di beberapa kasus tidak memiliki kontrol sama sekali atas informasi yang diberikan pada jurnalis. Seberapa banyak informasi yang diberikan akan dipakai para jurnalis, kapan informasi tersebut akan ditayangkan, hingga bagaimana pengemasan informasi tersebut menjadi wewenang dari jurnalis.

Patut dipahami bahwa praktik media relations yang melibatkan subsidi informasi dilakukan secara pamrih. Artinya, ada sebuah imbalan yang diharapkan dari pemberian informasi oleh PR tersebut. Imbalan yang diharapkan berupa citra maupun reputasi yang baik (Febriyansyah, Maylanny, dan Imran, 2016).

\section{Juru Bicara}

Pekerjaan PR pemerintah tentunya tidak bisa dilaksanakan seorang diri saja, karena dibutuhkan kerjasama tim yang solid. Lazimnya, tiap tim PR pasti memiliki seorang juru bicara. Hal ini dilakukan agar penerapan subsidi informasi terhadap rekan-rekan media berjalan melalui satu pintu saja. Di sisi lain, hal ini tentunya memudahkan para jurnalis untuk mencari pihak yang pasti dalam memberikan informasi pada mereka. Dalam konteks penelitian ini, juru bicara yang dimaksud adalah Juru Bicara Wakil Presiden.

Peran juru bicara dalam lingkungan istana semakin esensial. Juru bicara merupakan laki-laki ataupun perempuan yang memiliki tugas utama membangun dan menjaga hubungan baik dengan media (McNair, 2011).

Terkait hal ini, elit-elit di pemerintahan, termasuk wakil presiden di dalamnya, memang sumber berita yang dicari-cari media. Wakil presiden bisa saja menyampaikan informasi secara langsung, tapi tentunya tidak setiap hari. Oleh karena itu, keberadaan juru bicara esensial sebagai 'jembatan komunikasi' yang mampu memberikan informasi resmi sebagai perwakilan suara pemerintah secara berkala (Towle, 1997; McNair, 2011). Seitel (2015) menegaskan bahwa posisi juru bicara di lingkup istana merupakan pekerjaan yang sulit. Seorang juru bicara perlu meyakini pilihan pemimpinnya adalah tindakan yang tepat agar mampu mempersuasi masyarakat sesuai keyakinan tersebut.

Keberadaan juru bicara diharapkan mampu mempertahankan dan membangun citra maupun reputasi dari pihak yang direpresentasikannya. Terdapat dua karakteristik utama juru bicara istana (Towle, 1997). Pertama, juru bicara berperan sebagai boundary spanner. Tidak hanya menjadi corong bagi pihak yang diwakili, namun juru bicara juga diharapkan mampu menyerap aspirasi masyarakat. Kepercayaan terhadap juru bicara termasuk tinggi apabila ia juga berperan sebagai pihak yang memberi masukan (adviser) kebijakan bagi pemerintah. Konsekuensinya, seorang juru bicara tidak harus selalu tunduk dengan apa yang diputuskan atasannya. Seitel (2015, hlm. 269) menuliskan 'kesetiaan utamanya (juru bicara) adalah kepada publik dan ia tidak boleh membohongi atau menyesatkan pers'. Meski demikian, McNair (2011) berpandangan bahwa walau menerima gaji yang berasal dari APBN, loyalitas juru bicara lebih condong kepada pihak yang diwakilinya dan bukan pada rakyat.

Kedua, sejauh mana juru bicara diperbolehkan untuk menyebarkan informasi kepada publik melalui media. Dalam hal ini, juru bicara harus mengikuti kemauan pihak yang diwakilinya. Towle (1997) mengkategorikan hal ini menjadi dua poin yakni juru bicara yang hanya bertugas mendiseminasikan informasi dan juru bicara yang diperbolehkan memberi interpretasi atas pikiran maupaun tindakan wakil presiden.

Juru bicara sebagai bagian dari PR pemerintah diharuskan memiliki kompetensi 
yang tertuang dalam Peraturan Menpan Nomor PER/12/M.PAN/08/ Tahun 2007 tentang Pedoman Umum Hubungan Masyarakat di Lingkungan Instansi Pemerintah.

Cutlip dkk (2005) menilai etos kerja juru bicara haruslah proaktif. Dengan demikian, juru bicara perlu mengetahui perkembangan terkini atas isu-isu yang menyasar pihak yang direpresentasikan, sebelum isu itu bisa menjadi krisis. Tindakan preventif perlu dilaksanakan karena pemerintah adalah sasaran komunikasi. Cutlip dkk (2005) menyampaikan juru bicara pemerintahan perlu menempatkan diri mereka sebagai pembuat agenda. Implikasinya, informasi dapat berkembang sesuai dengan arah yang diinginkan. Dengan kata lain, juru bicara juga merupakan pelaku dari agenda setting.

\section{Agenda Setting dan Juru Bicara}

Teori agenda setting pertama kali diperkenalkan oleh McCombs dan Shaw ketika meneliti kampanye presiden di Amerika Serikat pada 1968, 1972, dan 1976 (University of Twente, 2019). Inti asumsi dari teori ini adalah informasi-informasi yang disampaikan di media massa secara konsisten dapat mempengaruhi masyarakat, sehingga menganggap isu tersebut sebagai hal yang penting. Lebih lanjut, apa yang tidak dianggap penting dan tidak ditampilkan di media akan serta merta luput dari mata publik. Dalam penerapan agenda setting, tiap informasi pasti melalui proses pembingkaian lebih dahulu (framing). Hal ini dilakukan demi mencapai reputasi serta citra yang diinginkan.

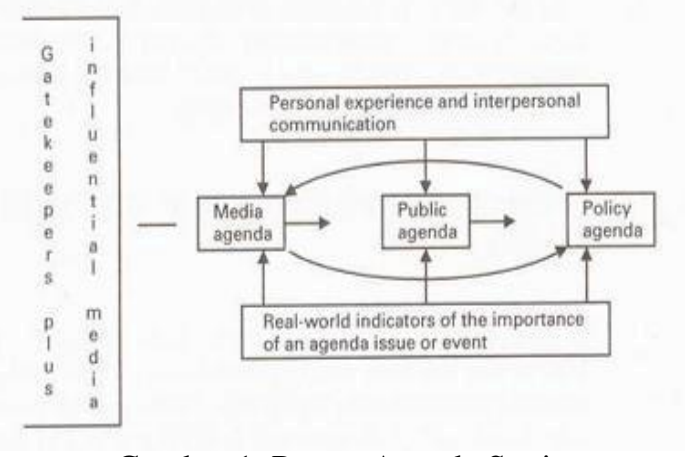

Gambar 1. Proses Agenda Setting Sumber: University of Twente (2019)
Sallot dan Johnson (2006) menjelaskan berita-berita yang ditayangkan media sebagian besar berasal dari informasi yang diberikan oleh juru bicara kepada media. Elfrida (2015) mengutip penelitian Judy VanSlyke Turk pada 1984 bahwa informasi yang disebarkan oleh enam pejabat informasi public lembaga pemerintah mempengaruhi pemberitaan delapan surat kabar di Louisiana. PR punya kekuatan untuk memengaruhi agenda media yang sejatinya hak prerogatif redaksional masing-masing media (Syahputra, 2018).

Lebih lanjut, kekuatan juru bicara saat ini dalam agenda setting begitu besar. Karena, wartawan-wartawan saat ini dihadapi dengan situasi miris, berupa peningkatan produksi berita dan batas waktu (deadline). Franklin dkk (2009) mengkategorikan wartawan saat ini sebagai wartawan pasif (passive journalist), sementara Taylor (2008) menyebutnya sebagai wartawan protokol (protocol journalist). Kedua istilah itu memiliki penjelasan yang serupa, yakni tipe wartawan yang serta merta menulis apapun materi informasi yang diberikan juru bicara pada mereka. Tipe wartawan ini tidak skeptis sama sekali sehingga bisa dianalogikan sebagai corong dari PR. Kritik terhadap praktik seperti ini adalah rendahnya kualitas produk jurnalistik.

Gandy (1982) menegaskan bahwa pemilihan media juga menjadi penting dalam penerapan agenda setting ini. Perlu ada pertimbangan matang untuk menentukan media mana yang akan dipilih dan media mana pula yang memberikan pengaruh publik secara maksimal. Sebab, beda media, beda pula publiknya.

\section{METODOLOGI PENELITIAN}

\section{Penelitian Kualitatif}

Metode yang digunakan dalam penelitian ini adalah metodologi penelitian kualitatif. Kriyantono (2012) menjelaskan metode penelitian kualitatif sebagai sebuah metode untuk menjelaskan suatu fenomena dengan pengumpulan data-data yang 
dikumpulkan dan diolah secara mendalam. Kriyantono (2012, hlm. 57) juga menuliskan bahwa 'riset (dengan metodologi kualitatif) ini bersifat subjektif dan hasilnya lebih kasuistik bukan untuk digeneralisasikan'. Chairi (2009) menambahkan dalam penelitian kualitatif terkandung sifat subjektif peneliti karena peneliti diharuskan untuk terjun langsung ke lapangan, untuk melakukan pengumpulan, pemilihan, hingga interpretasi data.

Penelitian ini pun berjenis penelitian deskriptif kualitatif. Sebab, peneliti membuat deskripsi secara sistematis, faktual, dan akurat tentang objek yang akan diteliti. Kriyantono (2012) menambahkan bahwa dalam jenis penelitian deksriptif tidak menjelaskan hubungan antarvariabel. Selain itu, Mulyadi (2011, hlm. 133) menambahkan 'pada suatu penelitian deskriptif, tidak menggunakan dan tidak melakukan pengujian hipotesis (berbeda dengan penelitian kualitatif jenis eksplanasi)'.

\section{Pendekatan Studi Kasus}

Penelitian ini menerapkan pendekatan studi kasus. Studi kasus, menurut Rahardjo (2017, hlm. 3), 'serangkaian kegiatan ilmiah yang dilakukan intensif, terinci, dan mendalam tentang suatu program, peristiwa, dan aktivitas, baik pada tingkat perorangan, sekelompok orang, lembaga atau organisasi untuk memperoleh pengetahuan mendalam tentang peristiwa tersebut'. Penelitian dalam kacamata studi kasus berusaha untuk menjawab pertanyaan tentang how (bagaimana) dan why (mengapa).

Penelitian studi kasus pun harus berlandaskan latar alamiah dan holistik (Rahardjo, 2017). Dalam studi kasus, metode pengumpulan data yang cenderung diterapkan adalah wawancara dan observasi.

\section{Teknik Pengambilan Data}

Dalam penelitian ini, peneliti menerapkan wawancara sebagai teknik pengumpulan data. Menurut Kriyantono
(2012), wawancara merupakan percakapan antara periset dan informan yang bersifat tidak terstruktur, yang bisa dilakukan beberapa kali demi mendapatkan data kualitatif yang mendalam. Berhubungan dengan penelitian ini, peneliti menggunakan teknik wawancara mendalam.

Wawancara tentu dilakukan terhadap informan. Informan kunci yang akan diwawancara untuk menunjang data kualitatif dari penelitian ini adalah Husain Abdullah selaku Staf Khusus Wakil Presiden Bidang Komunikasi dan Informasi.

\section{Profil Narasumber}

Husain Abdullah merupakan pria yang lahir pada 12 Agustus 1964, tepatnya di Parepare, Sulawesi Selatan. Husain menamatkan SD dan SMP di sekolah negeri di Parepare. Kemudian, ia melanjutkan studi di SMA Negeri 1 Makassar. Selanjutnya, jenjang Strata 1 untuk Program Studi Hubungan Internasional didapatkannya di Fakultas Ilmu Sosial dan Politik Universitas Hasanuddin pada 1988. Kemudian, pada 2009, Husain meraih gelar magister untuk Ilmu Komunikasi dari Universitas Hasanuddin.

Husain ditetapkan sebagai Juru Bicara Wakil Presiden Jusuf Kalla untuk dua periode. Periode pertama dimulai pada 2004-2009. Saat itu, Jusuf Kalla berpasangan dengan Presien Susilo Bambang Yudhoyono. Selanjutnya, ketika Jusuf Kalla berduet dengan Presiden Jokowi, Husain kembali ditetapkan sebagai Juru Bicara Wakil Presiden untuk periode 2014-2019.

Sebelum menjadi juru bicara, perjalanan karir Husain dimulai sebagai wartawan kontributor RCTI di Makassar sejak 1992 hingga 2008. Ia pernah menduduki jabatan penting di media, antara lain adalah Direktur Sun TV Makassar pada 2009-2010, dilanjutkan menjadi Pemimpin Redaksi Celebes TV Makassar pada 2010 hingga 2014. 


\section{HASIL DAN PEMBAHASAN}

Hasil penelitian ini secara garis besar dirumuskan setelah peneliti melakukan observasi selama tiga bulan dan ditunjang pula dengan mewawancarai narasumber kunci, yakni Husain Abdullah selaku juru bicara dari Wakil Presiden Jusuf Kalla pada periode 2014-2019. Observasi dilakukan dengan mengikuti beberapa kegiatan Husain Abdullah selaku Juru Bicara Wakil Presiden periode 2014-2019. Lokasi observasi ini bertempat di Istana Wakil Presiden, Jalan Medan Merdeka Nomor 6, RT 11/RW 02, Jakarta Pusat, dan di Kantor Wakil Presiden, Jalan Veteran III No. 14, RT 02/RW 03, Jakarta Pusat.

Dalam praktiknya, juru bicara bersama dengan pihak yang ia representasikan menyamakan persepsi lebih dulu atas citra seperti apa yang akan dibangun. Dalam ranah politik, citra berarti pandangan publik atas aktor politik (McNair, 2011). Penentuan citra menjadi langkah yang pertama, karena citra seorang wakil presiden, entah itu baik atau buruk, dapat memengaruhi citra pemerintahannya yang sedang dipimpin.

Citra wakil presiden memang bukanlah faktor tunggal dalam menentukan mulus atau tidaknya roda pemerintahan berjalan. Namun, hal-hal negatif yang tampak dan diingat publik atas seorang pemimpin, cenderung berdampak secara langsung maupun tidak langsung terhadap jalannya sebuah pemerintahan. Dalam konteks ini, citra yang berusaha dibangun oleh Wakil Presiden Jusuf Kalla (JK) adalah tokoh perdamaian (Awaluddin, 2009; Ponco dan Khoiri, 2011; Satriawan, 2018) dan negarawan atau politisi yang mementingkan kepentingan bangsa daripada ego pribadi (Kompas, 2014; RMOL Sumsel, 2019; Viva, 2019).

Setelah menyamakan persepsi soal citra apa yang mau dibangun serta dipertahankan, langkah berikut ialah menentukan publik sasarannya. Publik di sini tidak dapat dipahami sebagai publik secara luas, melainkan sebuah segmen yang spesifik. Suprawoto (2018) menuliskan bahwa terdapat empat tipe publik berdasarkan situasinya, yaitu publik semua isu (publik yang selalu bersuara atas isu apapun), publik apatis (publik yang tidak menaruh perhatian pada isu apapun), publik isu tunggal (publik yang menaruh perhatian pada satu isu khusus), dan publik isu hangat aktif (publik yang aktif atas sebuah isu yang dibahas secara masif di media).

Publik yang dituju ialah publik isu tunggal. Ada beberapa ciri khas dari publik jenis ini antara lain adalah, para individunya memiliki kompetensi edukasi yang mumpuni, serta menaruh minat yang sama terhadap satu isu tertentu walau belum tentu memiliki opini yang seragam.

"Ada audiens masing-masing memang,
tergantung isu. Misal kalau masalah
kelistrikan itu ya orang-orang industri
atau masyarakat yang concern ke sana,
yang lain kadang tidak peduli. Kalau
perbankan kan ada UMKM, ada
segmen tertentu... yang ikuti
perkembangan isu-isu di istana itu
sebenarnya adalah orang-orang yang
well educated. Tentu beda dengan yang
ikut isu kelurahan. Ini hasil pengalaman
saya menjadi jubir dua periode"
(Husain Abdullah, dalam wawancara,
2019).

Selanjutnya, Wakil Presiden Jusuf Kalla memberikan keleluasaan bagi Husain selaku juru bicara yang mewakilinya untuk melaksanakan fungsi-fungsinya. Keleluasaan yang dimaksud berarti, tiap langkah yang dilakukan juru bicara tidak perlu mengantongi izin dari wakil presiden. Di lingkungan istana, juru bicara secara umum leluasa dalam menjalankan dua tugas utama, yaitu fungsi komunikasi dan fungsi proteksi.

Fungsi komunikasi ini sejalan dengan UU No 14 Tahun 2008 tentang Keterbukaan Informasi Publik (KIP). Pemberian informasi ini umumnya diunggah di situs resmi wakil presiden yang bisa diakses di wapresri.go.id. serta dibantu pula oleh para wartawan yang sehari-hari bertugas di istana, dan juga dengan konten-konten di media sosial. Terkait dengan 
pemberian pernyataan kepada para wartawan, hal itu hanya boleh dilakukan wakil presiden sendiri dan juru bicara saja.

\begin{abstract}
"Seorang jubir itu punya peran untuk menghubungkan wapres dengan media. Secara structural di Kantor Wapres tidak ada yang boleh keluarkan informasi ke publik selain saya. Hanya ada satu pintu, ya melalui saya saja. Kebetulan Pak JK ini media darling, jadi saya tidak harus selalu tampil. Ada yang Pak JK sudah jelaskan dan clear" (Husain Abdullah, dalam wawancara, 2019).
\end{abstract}

Fungsi komunikasi ini dapat diklasifikasikan sesuai sistem komunikasinya menjadi dua yakni media arus utama atau pers, dan media sosial. Peneliti akan membedah dan membahas lebih dulu strategi komunikasi terhadap pers yang diterapkan oleh Juru Bicara Wakil Presiden Jusuf Kalla.

Untuk mewujudkan fungsi komunikasi ini, juru bicara menentukan satu hari tiap minggu untuk pers melakukan tanya jawab secara langsung dengan Wakil Presiden. Awalnya jadwal audiensi antara Wakil Presiden Jusuf Kalla dan para awak media dilaksanakan tiap Jumat, usai melaksanakan Sholat Jumat, pada 2014 hingga pertengahan 2015. Namun, karena pemintaan dari rekanrekan pers bahwa minimnya pembaca ataupun penikmat berita di Jumat, maka jadwal audiensi berubah. Kemudian, jadwal audiensi itu ditetapkan tiap Selasa, sekitar pukul 14.00 WIB. Dipilihnya Selasa karena bertepatan dengan jadwal Sidang Kabinet ataupun Sidang Rapat Terbatas. Setelah sidang, maka para wartawan bisa langsung melakukan wawancara. Dengan demikian, hasil wawancara itu dapat mengantongi nilai berita yang tinggi, sehingga layak diberitakan.

Dari perubahan jadwal audiensi itu bisa dipahami bahwa juru bicara juga menampung aspirasi dari rekan-rekan pers, kemudian meresponsnya. Hal ini sejalan dengan praktik media relations, dimana juru bicara sebagai PR pemerintah mengayomi rekan-rekan pers.

Model wawancara dengan para rekanrekan pers ini juga tergantung dengan situasi.
Modelnya bisa berupa door-stop atau wawancara yang dilakukan secara spontan usai narasumber melakukan kegiatan tertentu. Awak pers lebih gemar melakukan wawancara secara door-stop karena ada kecenderungan wartawan malu bertanya di hadapan banyak orang, tapi berani bertanya bila ramai-ramai dengan sesama rekan profesinya (Indonesia PR, 2016).

Sementara, di lain kesempatan bisa berbentuk konferensi pers. Konferensi pers merupakan aktivitas humas dalam melaksanakan subsidi informasi yang memenuhi nilai berita kepada rekan-rekan pers dalam jumlah besar yang sudah dikumpulkan dalam satu tempat (Butterick, 2014). Usai konferensi pers, para rekan pers biasanya mendapat jamuan makan.

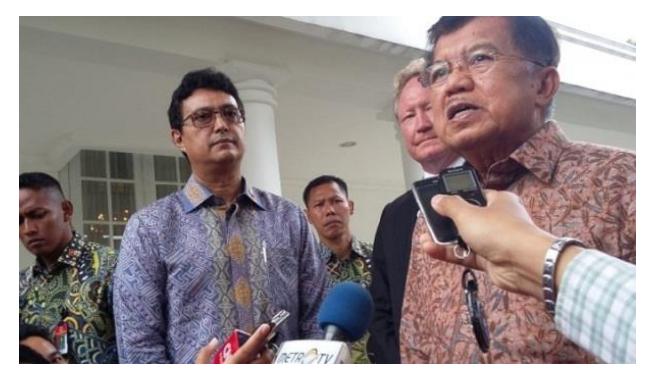

Foto 1. Model Door-stop (Sundoro, 2017)

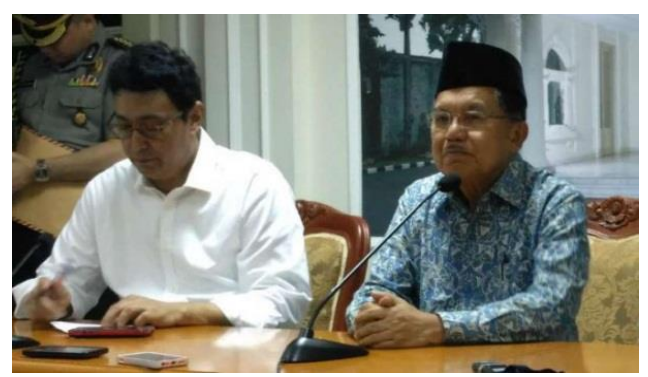

Foto 2. Model Konferensi Pers (Viva, 2018)

Apabila wakil presiden berhalangan maka menjadi tugas dari juru bicara untuk memenuhi kebutuhan informasi tersebut. Saat melakukan fungsi komunikasi ini, pernyataan yang keluar dari mulut juru bicara harus mengacu dan senada dengan pernyataan wakil presiden. Namun, juru bicara dibolehkan untuk memberi tafsir atas pesan yang disampaikan oleh pihak yang direpresentasikan.

"Wapres bilang A, jubir tidak boleh bilang $\mathrm{B}$ apalagi menafsirkan secara 
menyimpang atau keliru dari pernyataan yang butuh follow up media. Yang terpenting itu menangkap pesan dan menerjemahkan apa yang ingin disampaikan wapres. Hubungan keduanya (antara wapres dan juru bicara) itu harus sejiwa sehingga tektok sudah dipahami. Jadi saya sudah tahu mau wapres apa" (Husain Abdullah, dalam wawancara, 2019).

Penelitian yang dilakukan Towle (1997) mengkategorikan juru bicara menjadi dua tipe. Pertama, juru bicara yang hanya berperan sebagai penyambung lidah. Artinya, juru bicara hanya menyampaikan pesan wakil presiden saja, tanpa mengubah isi pesan tersebut. Tipe kedua adalah juru bicara yang diperbolehkan menjadi representatif. Juru bicara tipe kedua ini diperbolehkan untuk memberikan interpretasinya atas pesan wakil presiden yang dititipkan kepadanya. Mengacu pada kutipan wawancara di atas, maka dapat disimpulkan Husain Abdullah termasuk dalam kategori tipe kedua, yakni juru bicara representatif, karena ia diberi keleluasaan untuk menganalisa dan menginterpretasikan pesan Wakil Presiden Jusuf Kalla.

Agar tidak salah menginterpretasikan maksud wakil presiden, diperlukan komunikasi yang intensif. Komunikasi ini harus dibangun tiap hari, baik dalam hal formal dan informal. Untuk hal formal, tentunya juru bicara mendampingi wakil presiden sesuai jadwal hariannya. Salah satu contohnya adalah mendampingi wakil presiden ketika audiensi ataupun rapat dengan para menteri, pebisnis-pebisnis, ataupun politisi-politisi, dan ikut pula ketika melakukan kunjungan kerja keliling Indonesia bertemu dengan berbagai elemen masyarakat.

Ada sedikit pembeda dalam menjaga komunikasi di lingkungan istana. Husain menjelaskan bahwa di dalam lingkungan istana, ada batasan-batasan yang mengikat. Misalnya saja rapat terbatas antara presiden, wakil presiden, dan beberapa menteri terkait. Tentu posisi juru bicara tidak bisa ikut dalam acara itu.
Selain itu, ada pula batasan di luar lingkungan istana, khususnya di forum-forum internasional. Juru bicara tetap dalam posisi yang selalu ikut serta dalam tiap kegiatan wakil presiden. Meski demikian, akses seorang juru bicara terbatas di forum-forum internasional. Dalam kondisi demikian, komunikasi antara wakil presiden dan juru bicara tetap harus dibangun. Salah satu contoh adalah Husain ikut serta dalam rombongan Wakil Presiden Jusuf Kalla ketika menghadiri Sidang Umum PBB ke 74 di New York, Amerika Serikat, pada 23 September 2019. Dalam forum tersebut, akses untuk ikut serta dalam konferensinya terbatas bagi para perwakilan kepala negara saja.
"Setelahnya (rapat terbatas atau pertemuan skala internasional) saya selalu ajak wapres diskusi, poin-poin pembahasannya apa saja sih tadi. Jadi ini persiapan bilamana media bertanya. Jadi kalau tidak ikut, kita tetap update dan kalau diperlukan untuk pertanyaan media, ya bisa dijawab" (Husain Abdullah, dalam wawancara, 2019).

Lebih lanjut, juru bicara juga perlu masuk dalam keseharian atau ranah privat dari pihak yang ia wakili.

"Saya sebagai jubir tidak kenal jam kerja. Tidak seperti PNS, jam 4 selesai ya pulang rumah dan tidur. Tapi saya tidak posisikan diri seperti itu, saya kapan saja diperlukan, anytime, ya saya gerak" (Husain Abdullah, dalam wawancara, 2019).

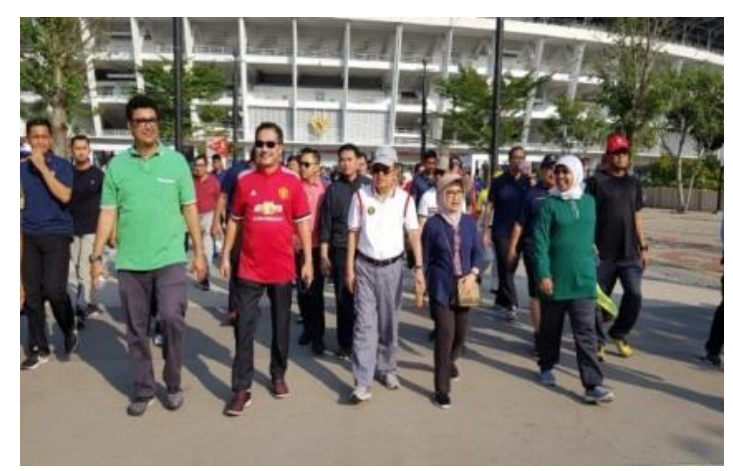

Foto 3. (Kumparan, 2019) 


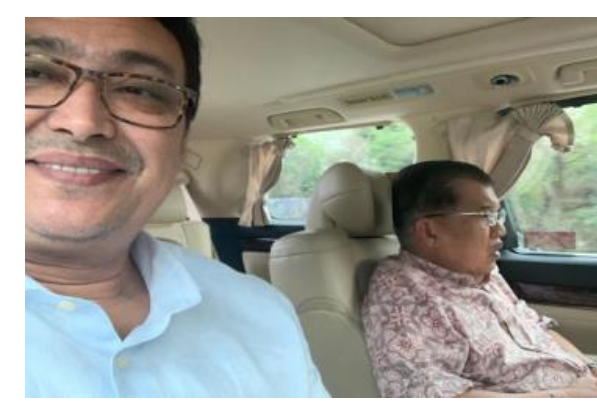

Foto 4. Dokumentasi pribadi

Seperti yang diungkapkan di atas, selain pers, Juru Bicara Wakil Presiden juga mendapat mandat untuk mengelola media sosial. Ada dua media sosial yang menjadi fokus dari Wakil Presiden Jusuf Kalla yaitu Twitter@Pak_JK dengan 2,95 juta pengikut dan Instagram@jusufkalla dengan 234 ribu pengikut (diakses pada 4 Desember 2019). Semua konten yang akan diunggah di kedua akun media sosial tersebut harus mendapat izin dari Husain Abdullah selaku juru bicara. Ia pun diberikan keleluasaan tidak perlu melapor kepada Jusuf Kalla.

Konten yang diunggah di media sosial hanya konten-konten bersifat emosional seperti ucapan selamat hari raya ataupun ucapan belasungkawa, dan konten yang menampilkan kehidupan pribadi seperti menghabiskan waktu luang bersama keluarga. Pengungkapan kehidupan pribadi elit politik memang dilakukan supaya wakil presiden mendapat kesan dekat dengan rakyat serta tidak ada hal-hal yang perlu ditutup-tutupi (Alvin, 2019).

Sementara, konten-konten yang berkaitan dengan program kerja pemerintah, porsi unggahanya minimal. Walaupun kontrol konten media sosial ada di tangan pengguna (Alvin, 2019), Husain mengatakan ada peluang masyarakat bisa salah tangkap informasi.

"Di medsos yang ringan-ringan supaya lebih akrab dengan masyarakat, lebih mendekatakan, supaya ada human interest, lebih kena emosionalnya. Misal ada bencana alam, ada ucapan belasungkawa, dan itu bisa cepat... tapi jujur saja jarang saya gunakan akun Pak JK untuk program-program pemerintah. Saya bukan membatasi, tapi saya tidak perlu buka semua, karena di media sosial sifatnya sepotong-sepotong" (Husain Abdullah, dalam wawancara, 2019).

Penting bagi juru bicara untuk memilahmilah pesan yang akan disebarluaskan kepada publik. Juru bicara perlu menimbang dampak atau implikasi yang ditimbulkan dari informasi yang diungkap kepada publik. Kaidah utamanya ialah tidak membongkar rahasia negara dan tidak membuat gaduh

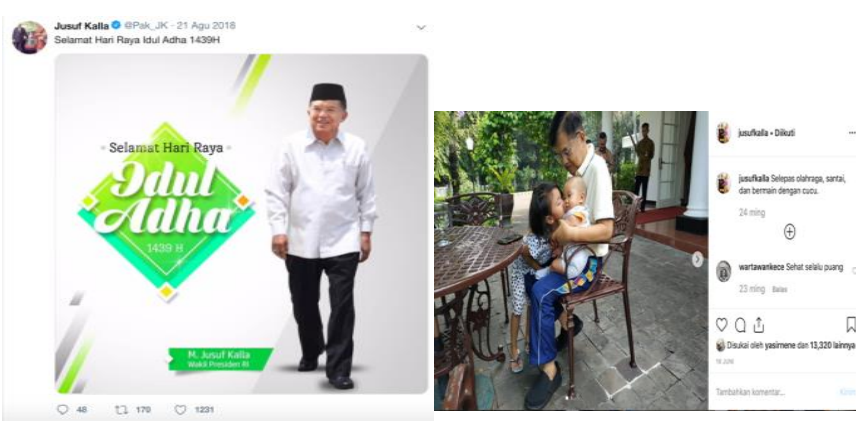

Foto 5 dan 6. Twitter@Pak_JK dan@jusufkalla.

Salah satu contoh kegaduhan akibat salah menentukan unggahan konten adalah vlog Presiden Jokowi bermain dengan cucunya Jan Ethes. Unggahan itu menuai kritik dan cibiran dari publik. Tidak ada yang salah dalam konten di vlog tersebut, hanya saja waktu (timing) mengunggahnya tidak tepat. Saat itu, sedang terjadi bencana asap akibat kebakaran hutan di Sumatera dan Kalimantan. Ribuan masyarakat Indonesia kesulitan bernafas karena terganggu asap. Oleh sebab itu, konten Jokowi bermain dengan cucunya di halaman Istana Bogor menuai kecaman karena seakan-akan presiden tidak peduli dengan bencana yang menimpa rakyatnya (Diana, 2019). Seleksi atas kontenkonten yang mau diunggah di media sosial haruslah dipikirkan secara strategis dengan menimbang dampak yang ditimbulkan.

"Di sini butuh kepekaan dari Jubir untuk melihat dan mengukur sejauh mana kadar informasi apa yang layak disampaikan pada publik. Apakah itu menyangkut national security atau faktor sosial atau faktor-faktor lainnya yang harus dipertimbangkan, soal 
stabilitas pemerintahan dan negara, dan juga timing. Jangan sampai ada kegaduhan. Kalau ada empat pesan, mungkin cukup satu pesan saja dulu yang disampaika" (Husain Abdullah, dalam wawancara, 2019).

Juru bicara dituntut untuk hati-hati dan cermat dalam membagikan informasi kepada publik. Sebab, kesalahan dalam penyebarluasan informasi dapat menciptakan kegaduhan politik yang berujung menganggu stabilitas politik sebuah negara (Badrun, 2017).

Dengan demikian, juru bicara diperbolehkan untuk melakukan swasensor. Hal ini tidak melanggar aturan maupun kode etik dari seorang juru bicara. Terdapat beberapa hal yang boleh dirahasiakan ataupun dilakukan swasensor oleh juru bicara, yakni 'national security and international relations; personal privacy; commercial confidentiality; law enforcement; public order; information received in confidence; internal regulations' (Suprawoto, 2018, hlm. 235). Poin-poin tersebut tercantum pula di Undang-Undang Keterbukaan Informasi Publik Nomor 14 Tahun 2008 Pasal 17.

McNair (2011, hlm 45) menuliskan 'politicians, however, also seek to conceal information from citizens, sometimes for reasons of what is called "national security" and sometimes to avoid political embarrassment'. Pernyataan McNair itu mengingatkan bahwa adanya potensi bagi juru bicara dalam memanfaatkan celah dalam aturan. Penerapan swasensor ini haruslah sejalan dengan adagium latin yang berbunyi quid leges sine moribus (Suprawoto, 2018) yang berarti celah hukum jangan sampai dimanfaatkan sehingga mengebiri moralitas.

\footnotetext{
"Kita memang harus pandai-pandai mengelola isu, bukan membatasi tapi mengelola komunikasi, supaya apa yang kita sampaikan itu jangan jadi kata kunci dari suatu permasalahan. Di situ peran jubir. Idealnya ada agenda setting tanpa harus menutupi fakta" (Husain Abdullah, dalam wawancara, 2019).
}

Salah satu temuan yang cukup menarik adalah Husain Abdullah juga diberi kesempatan untuk memberikan masukanmasukan (spokesperson also act as an advisor). Ini berarti juru bicara juga menerapkan konsep boundary spanner, yakni juru bicara mengamati kondisi nyata di lapangan dan kemudian melaporkan situasi yang terjadi (Grunig, 2002 dalam Prasetyo, 2016, hlm. 20).

"Kalau ketemu, Pak JK mulai kalimat dengan katakan gimana perkembangan di luar. Itu kesempatan saya beri input dan beri update atas situasi objektif yang sedang berlangsung di luar... Misal soal rencana kenaikan iuran BPJS. Nah, bapak pernah tanya gimana perkembangan di luar. Saya jawab ada resistensi dari masyarakat terutama dari kalangan bawah. Kira-kira demikian, saya sampaikan info yang didapat langsung dan dari media maupun juga dari macam-macam diskusi" (Husain Abdullah, dalam wawancara, 2019).

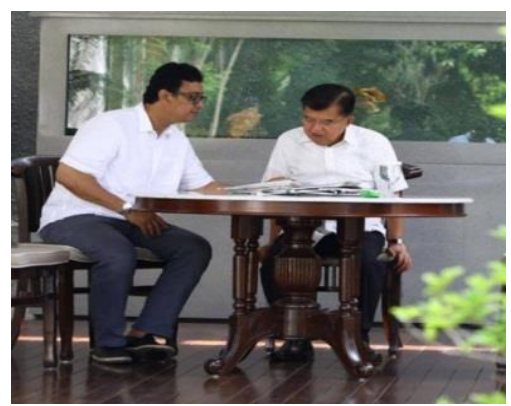

Foto 7. Dokumentasi pribadi Husain Abdullah

Agar kredibel dalam memberikan masukan, juru bicara perlu pula menyerap aspirasi masyarakat. Bagi peneliti, penyerapan aspirasi masuk dalam fungsi komunikasi, khususnya dalam mewujudkan komunikasi dua arah. Jadi, komunikasi itu tidak hanya satu arah dari pemerintah ke masyarakat semata, melainkan bisa sebaliknya.

Dari penyerapan aspirasi itu pula, akan diketahui pula bila ada isu-isu tertentu yang berpotensi menjadi krisis. Butterick (2014) menjelaskan krisis sebagai timbulnya keraguan dan kecurigaan hingga berujung 
pada jatuhnya citra orang maupun organisasi atas sebuah isu yang terlambat ataupun salah ditanggapi.

Oleh karena itu, bila ada beberapa isu yang sudah dideteksi, maka juru bicara langsung melakukan fungsi proteksi sebagai taktik yang melindungi citra personal Wakil Presiden Jusuf Kalla sekaligus melindungi citra pemerintah.

\begin{abstract}
"Idealnya sebenarnya jubir pemerintah. Jujur saya subjektif lebih back-up Pak JK. Karena apa yang sampaikan itu toh program pemerintah. Tugas saya memang kawal Wapres dalam hal ini Pak JK, mengawal tiap pernyataan beliau ke publik. Dengan mengamankan Pak JK, saya amankan juga program pemerintah" (Husain Abdullah, dalam wawancara, 2019).
\end{abstract}

Petikan wawancara di atas juga sekaligus memperkuat argumentasi McNair (2011) bahwa loyalitas juru bicara itu lebih condong pada orang yang ia representasikan, meskipun penghasilan yang diterima didapat dari negara.

Dalam menjalankan fungsi proteksi, Juru Bicara Wakil Presiden dibantu dengan anggota yang berisikan 20 orang di bawahnya (non-PNS dan PNS di bawah Sekretariat Wakil Presiden dengan kualifikasi pemahaman jurnalistik dan politik), melakukan manajemen krisis.

Penerapan manajemen krisis yang diterapkan adalah pemantauan media atau media monitoring. Farihanto (2014) menulis bahwa media monitoring berguna untuk mengetahui sentimen publik akan suatu isu, apakah kecenderungannya itu positif atau negatif. Selain itu, dari media monitoring pula dapat diketahui isu mana yang mulai jadi perhatian publik dan isu mana yang mulai ditinggalkan publik. Isu-isu tersebut dipantau, agar sewaktu-waktu isu menjadi krisis maka bisa langsung diantisipasi.

Media monitoring ini tidak hanya fokus memantau isi pemberitaan pada media arus utama saja, melainkan juga memantau kontenkonten di media sosial yang membahas tentang Wakil Presiden Jusuf Kalla. Hasil atas media monitoring ini dilaporkan tiap hari kepada juru bicara.
"Sekarang ini malah jubir itu butuh melakukan kerja-kerja intercept. Kita harus lihat tren (berita-berita) di media online dan di media sosial" (Husain Abdullah, dalam wawancara, 2019).

Salah satu contoh kasus adalah Partai Perindo mengajukan uji materi ke Mahkamah Konstitusi perihal masa jabatan wakil presiden. Beberapa portal berita online, antara lain seperti Indo Pos (Rahman, 2018), Kumparan (Saputra dkk, 2018), dan Merdeka (Mardani, 2018), serta beberapa portal berita lainnya menayangkan berita yang mengutip pernyataan Direktur Eksekutif Freedom Institute Rizal Mallarangeng maupun pengamat politik dari LIPI Syamsuddin Haris, yang menyebut Jusuf Kalla bernafsu terus berkuasa.

Tentunya pemberitaan sejenis itu bisa menghancurkan citra Jusuf Kalla yang dikonstruksikan sebagai seorang negarawan. Agar isu ini tidak menjadi krisis yang berlarutlarut, Husain Abdullah selaku juru bicara langsung membendung dengan menerapkan agenda setting. Husain berkomentar di portal berita online bahwa Jusuf Kalla adalah tokoh yang tidak haus kekuasaan. Hubungan JK hanya sebagai pihak terkait (Rini, 2018; Teresia dan Riso, 2018; Ayu, 2018).

Berada di dalam era komunikasi digital saat ini, Husain Abdullah menilai kerja juru bicara akan makin berat ke depannya. Salah satunya karena mereka juga dibebani dengan manajemen komunikasi politik di ranah dunia maya. Saat ia menjabat sebagai juru bicara di era SBY-JK pada 2004-2009, tugasnya meladeni komunikasi dengan rekan-rekan pers saja. Namun, di era Jokowi-JK, tepatnya pada akhir 2017, muncul fenomena buzzer politik. Felicia dan Loisa (2018) menjelaskan bahwa buzzer adalah kumpulan profesional ataupun relawan yang melakukan kampanye politik di dunia maya, bisa dengan mempromosikan atau menyerang tokoh dan atau kebijakan tertentu. 
Manakala ada buzzer politik yang menganggu, maka juru bicara di era komunikasi digital ini pun wajib turun tangan. Sebab, Carraro dkk (2012) menegaskan bahwa serangan politik yang didiamkan malah akan berbahaya karena akan timbul kesan seolah-olah informasi yang disampaikan itu benar. Poin yang menarik adalah Husain tidak menggunakan akun Wakil Presiden Jusuf Kalla untuk secara langsung membalas beragam serangan di media sosial. Respon justru dilakukan melalui akun media sosial si juru bicara.

Lebih lanjut, langkah yang diambil Husain adalah merespon serangan buzzer di platform media yang sama pula. Langkah tersebut senada dengan temuan dari tesis Alvin (2017) bahwa tidak akan ada dampak berarti bila membalas serangan politik di media yang berbeda dari asal serangan tersebut. Secara sederhana, bila ada yang menyerang di Instagram, maka perlu pula dibalas melalui platform yang sama, yaitu Instagram pula.

"Supaya netizen itu tidak menyerang langsung Pak JK macam-macam, karena itu akan ganggu reputasinya. Sebagian saya ambil alih melalui akun saya" (Husain Abdullah, dalam wawancara, 2019).

Dalam pernyataan Husain di atas, akun media sosial pribadi miliknya yang merespon serangan di media sosial terhadap Wakil Presiden Jusuf Kalla. Meski belum terukur seberapa efektif strategi ini, Husain mengklaim strategi ini berhasil meredam serangan yang terjadi di media sosial.

Tahapan-tahapan strategi komunikasi politik yang diterapkan oleh Husain Abdullah juga diikuti dengan evaluasi. Cangara (2016) mencatat bahwa evaluasi itu bisa terbagi menjadi dua yakni evaluasi formatif (evaluasi yang dilakukan bersamaan dengan pelaksanaan strategi komunikasi politik) dan evaluasi sumatif (evaluasi menyeluruh usai diterapkannya strategi komunikasi politik.

Dalam evaluasi formatif, Husain mengakui pernah kebablasan menggunakan keleluasaan yang diberikan Wakil Presiden
Jusuf Kalla atas dirinya. Salah satu kasus adalah ketika Wakil Presiden Jusuf Kalla dianggap berbeda paham dengan Presiden Jokowi. Hal itu pun menimbulkan kegaduhan politik akibat 'digoreng' oleh aktor-aktor politik. Bagi Husain, bila didiamkan maka isu perbedaan suara antara Presiden Jokowi dan Wakil Presiden Jusuf Kalla akan semakin liar.

Oleh karena itu, Ketika mendapat tawaran untuk tampil dalam diskusi di media, Husain tanpa mengantongi izin pun hadir. Padahal, Jusuf Kalla sebenarnya tidak mau Husain tampil di media. Di sini terlihat bahwa juru bicara sedekat apapun hubungannya dengan individu yang ia representasikan, tetap terbuka peluang adanya salah interpretasi. Keleluasaan dalam bertindak, memutus, hingga interpretasi pernyataan itu juga memiliki risiko tersendiri (Seitel, 2015).

\footnotetext{
"Kebanyakan saya banyak dilarang tapi saya nakal saja tampil di media. Karena ketika saya rasa penting untuk diluruskan dan begitu saya hitunghitung berbahaya atau tidak baik untuk Pak JK, saya tidak bilang dan langsung hadir saja di media... Tidak pernah saya ditegur. Misal Pak JK kebetulan buka TV lalu lihat saya, malah dia SMS saya untuk menambah informasi. Sampaikan ini dan sampaikan itu. Jadi saya dipandu sms dari Pak JK kemudian ya saya tambahkan" (Husain Abdullah, dalam wawancara, 2019).
}

Dalam evaluasi sumatif, bisa disimpulkan strategi komunikasi politik yang diterapkan sudah memenuhi citra yang telah ditetapkan di awal. Hal itu bisa tampak terlihat dari tanggapan maupun sentimen pers dan juga publik sasaran di akhir masa jabatan Jusuf Kalla sebagai Wakil Presiden RI. Pers mengapresiasi dengan membuat produkproduk jurnalistik yang bersentimen positif atas kinerja Jusuf Kalla. Selain itu, tidak ada kritik-kritik ataupun kegaduhan yang menyasar kepada Jusuf Kalla.

Ending Pak JK itu mulus, summa cumlaude, ada yang lepas dengan pesawat tempur, banyak pula opini positif di media sosial berterima kasih ke Pak JK. Semua itu karena approach 
komunikasi politik yang baik. Bila komunikasi politik buruk yang ada pasti cibiran, dan salah jubirnya itu dalam mengelola informasi (Husain Abdullah, dalam wawancara, 2019).

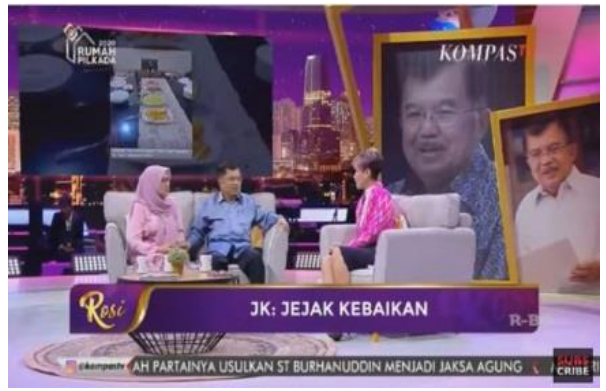

Foto 8. Kompas TV(2019)

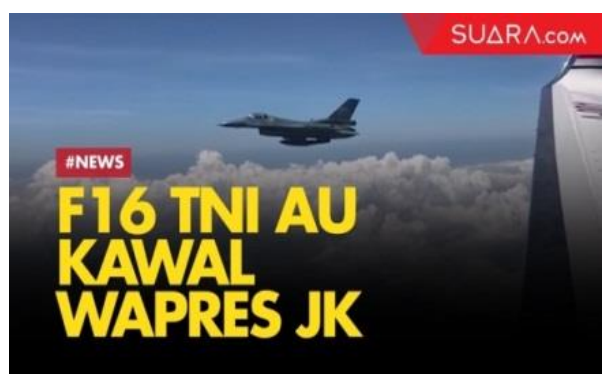

Foto 9. Suara (2019)

\section{PENUTUP}

Pasca reformasi menempatkan Indonesia dalam babak baru yakni era keterbukaan informasi. Pemerintah Indonesia dituntut untuk membuka pintu informasi itu sebagai bentuk tanggung jawab terhadap publik demi tercapainya pemerintahan yang baik. Keterbukaan informasi ini perlu dilakukan secara strategis, karena itu diperlukan tenaga dari praktisi government $P R$.

Wakil Presiden Republik Indonesia sebagai bagian dari pemerintah itu sendiri wajib menyampaikan informasi-informasi kepada publik. Meski demikian, tugas pokok dan fungsi dari wakil presiden tidak sebatas pada penyampaian informasi saja. Lebih lanjut, tata cara komunikasi yang tidak tepat dari sisi pemerintah dapat menimbulkan rendahnya kepercayaan publik sehingga bisa berefek pada hilangnya kepercayaan terhadap pemerintah secara menyeluruh.

Dalam upaya menghindari hal tersebut, Wakil Presiden Jusuf Kalla menunjuk Husain Abdullah sebagai juru bicaranya (government
$P R$ ). Husain Abdullah sebagai Juru Bicara Wakil Presiden 2014-2019 diberikan keleluasaan dalam menentukan strategi komunikasi politik yang ia rasa penting dilakukan, tanpa perlu melapor ataupun mendapat persetujuan dari Jusuf Kalla sebagai pihak yang direpresentasikan. Selama menjabat untuk periode 2014-2019, terdapat beberapa strategi komunikasi politik yang diterapkan oleh Husain.

Pertama, menentukan citra seperti apa yang mau dibangun serta dipertahankan. Langkah awal ini penting karena bila citra wakil presiden buruk, maka citra pemerintah juga akan berdampak negatif pula. Dalam tahap ini, citra yang ditentukan adalah tokoh perdamaian dan negarawan.

Kemudian, langkah berikutnya ialah menentukan publik sasaran, yakni publik isu tunggal. Karakterisitik dari publik jenis ini adalah memiliki edukasi yang baik dan mengikuti satu isu spesifik yang dianggap penting oleh mereka. Meski fokus pada isu yang sama, publik jenis ini belum tentu memiliki opini yang sama.

Setelah dua tahapan di atas dilakukan, barulah Husain selaku Juru Bicara Wakil Presiden menjalankan fungsi komunikasi dan fungsi proteksi. Keduanya guna mencapai citra yang sudah ditentukan sebelumnya di benak publik sasaran. Satu hal yang jadi temuan menarik adalah Husain diberikan wewenang untuk memutuskan langkah apa yang dianggapnya baik. Jadi, tidak diperlukan proses birokratis ketika Husain melaksanakan tugasnya sebagai seorang juru bicara.

Fungsi komunikasi dilakukan dengan menerapkan manajemen komunikasi berupa penyampaian informasi publik melalui pers dan juga melalui media sosial. Penyebaran informasi kepada rekan-rekan pers dilakukan bisa dengan model door-stop atau konferensi pers. Bila Jusuf Kalla berhalangan diwawancarai pers, maka Husain bisa menggantikan. Husain pun diberikan keleluasaan untuk memberikan pernyataan dengan menginterpretasikan situasi. Selain itu, ia juga dapat berperan sebagai penasihat (advisor) bagi wakil presiden. 
Sementara, untuk konten di media sosial hanya difokuskan pada Instagram dan Twitter saja. Segala konten yang diunggah hanya perlu persetujuan lebih dulu dari Husain, tanpa perlu persetujuan langsung dari Jusuf Kalla.

Selanjutnya, penerapan fungsi proteksi bisa diartikan pula sebagai bentuk manajemen krisis. Sebagai tokoh politik sentral di Indonesia, Wakil Presiden Jusuf Kalla bisa saja sewaktu-waktu terkena krisis. Bila tanpa persiapan, maka citra yang berusaha dibangun dan dijaga dapat runtuh. Oleh karena itu, strategi yang diterapkan adalah pengawasan media, baik di media arus utama dan juga media sosial.

Serangkaian tahapan di atas pada akhirnya juga melewati proses evaluasi. Terdapat dua skema evaluasi yang dilakukan, yakni evaluasi formatif dan evaluasi sumatif. Evaluasi diperlukan untuk mengetahui apakah strategi yang digunakan masih dalam jalur yang tepat atau tidak.

Penelitian ini diharapkan dapat menjadi wawasan baru bagi perkembangan komunikasi politik karena spesifik membahas peran dan strategi juru bicara di lingkungan istana. Strategi yang sama bisa diterapkan oleh para juru bicara tokoh politik lainnya. Tidak hanya itu, peneliti juga berharap penelitian ini menjadi landasan akademis bahwa keberadaan juru bicara itu esensial di lingkungan istana, terlebih di era keterbukaan informasi saat ini. Peneliti juga sadar bahwa penelitian ini jauh dari kata sempurna. Di masa mendatang, diharapkan ada penelitian lanjutan yang berangkat dari topik ini.

\section{DAFTAR PUSTAKA}

Alvin, S. (2017) Responding to Blasphemy Accusations in Indonesian Electoral Politics: A Case Study of Ahok's Online Communication Strategy through YouTube during Jakarta's Gubernatorial Election 2017. Thesis (MA), University of Leicester.

Alvin, S. (2019) Manajemen Citra Politik
Prabowo Subianto dan Sandiaga Uno Melalui Akun@Prabowo dan @Sandiuno, Jurnal Komunika, 13 (2), hlm. 93-111.

Arofi, A. M. (2018) Strategi Government Public Relations Kementerian Komunikasi dan Informatika dalam Mengelola Isu Publik. (Skripsi) Universitas Islam Negeri Syarif Hidayatullah.

Awaluddin, H. (2009) Perdamaian Ala JK: Poso Tenang, Ambon Damai. Jakarta: Grasindo.

Badrun, U. (2017) Konseptualisasi dan Aktualisasi Wawasan Kebangsaan di Era Global: Upaya Menghadirkan Konsep Sistem Politik Berdasarkan Wawasan Kebangsaan, Prosiding Universitas Negeri Medan, hlm. 206212.

Budiardjo, M. (2008) Dasar-dasar Ilmu Politik. Jakarta: Gramedia Pustaka Utama.

Butterick, K. (2014) Pengantar Public Relations: Teori dan Praktik. Jakarta: RajaGrafindo Perkasa.

Cangara, H. (2016) Komunikasi Politik: Konsep, Teori, dan Praktik. Edisi 5. Jakarta: Rajawali Pers.

Chairi, A. (2009) Landasan Filsafat dan Metode Penelitian Kualitatif, Dalam: Workshop Metodologi Penelitian Kuantitatif dan Kualitatif, Fakultas Ekonomi Universitas Diponegoro Semarang, hlm. 1-27.

Cutlip, S. M. dkk. (2005) Effective Public Relations. Jakarta: Penerbit Indeks.

Darmawan, Y. (2016) Husain Abdullah: Dari Jurnalis, Jubir Wapres, Hingga Walikota. Dapat diakses di: http://www.timurangin.com/2016/10/husain-abdullahdari-jurnalis-jubir.html (diakses pada 10 September 2019).

Djusan, A. (2012) Praktik Government Public Relations Paska Otonomi Daerah, Jurnal Studi Komunikasi dan Media, 16, hlm. 61-70. 
Dwiyanto, D. (2002) Metode Kualitatif: Penerapannya dalam Penelitian. Diakses dari: https://www.academia.edu/download/4 5555425/metode_kualitatif_penerapann ya_dalam_penelitian.pdf (diakses pada 28 September 2019).

Elfrida, S. V. (2015) Proses Membangun Agenda Setting Kebijakan Pada Portal Berita Pemerintah dan Kesesuaiannya dengan Agenda Media Online, Jurnal Masyarakat Telematika dan Informasi, 6, hlm. 13-26.

Farihanto, M. N. (2014) Teman tapi Mesra Humas dan Wartawan: Studi Kasus Hubungan Media di Bidang Humas Protokoler Universitas Ahmad Dahlan, Jurnal Profetik, 7 (2), hlm 53-64.

Febriyansyah, A. R., Maylanny, C., dan Imran, A. I. (2016) Strategi Media Relations PT. Pelabuhan Tanjung Priok dalam Menangangi Krisis, Jurnal Kajian Komunikasi, 4 (2), hlm. 229241.

Felicia dan Loisa, R. (2018) Peran Buzzer Politik dalam Aktivitas Kampanye di Media Sosial Twitter, Jurnal Koneksi, 2 (2), hlm. 352-359.

Franklin, B. dkk (2009) Journalism, News Sources and Public Relations. Chapter 19 in Allan, S (ed) The Routledge Companion to News and Journalism. London: Routledge.

Hasjanah, K. (2019) Dua Kali Dipercaya Jadi Wakil Presiden, Jusuf Kalla Beberkan Pengorbanannya. Dapat diakses di: https://www.tribunnews.com/nasional/ 2019/08/12/dua-kali-dipercaya-jadiwakil-presiden-jusuf-kalla-beberkanpengorbanannya?page $=4$ (diakses pada 10 September 2019).

Herlina, S. (2015) Strategi Komunikasi Humas dalam Membentuk Citra Pemerintahan di Kota Malang, JISIP, 4 (3), hlm. 493-500.

Indonesia PR (2016) Door Stop Interview. Dapat diakses di: https://indonesiapr.id/doorstop- interview/ (Diakses pada: 4 Desember 2019).

Kadir, K. (2009) Humas Pemerintah dan Pencitraan: Studi tentang Peran Humas dalam Pencitraan Malang sebagai Kota Pendidikan. (Tesis), Universitas Muhammadiyah Malang.

Kambie, A.S. (2016) Inilah Husain Abdullah. Dapat diakses di: https://makassar.tribunnews.com/2016/ 07/25/inilah-husain-abdullah?page $=2$ (diakses pada 10 September 2019).

Kompas (2014) Bagir: Jokowi-JK, Negarawan yang Sedang Tumbuh dan Negarawan Mapan. Kompas.com. Dapat diakses di: https://nasional.kompas.com/read/2014 /04/15/1156466/Bagir.Jokowi-

JK.Negarawan.yang.Sedang.Tumbuh.d an.Negarawan.Mapan (Diakses pada 4 Desember 2019).

KompasTV (2019) JK: Jejak Kebaikan ROSI. [Youtube] Dapat diakses di: https://www.youtube.com/watch?v=P5 766NHH2ks (Diakses pada 3 Desember 2019).

Kriyantono, R. (2012) Teknik Praktik Riset Komunikasi. Jakarta: Kencana.

Kumparan (2019) Wapres JK Olahraga Pagi Bareng Warga di GBK. Kumparan. Dapat diakses di: https://kumparan.com/kumparannews/ wapres-jk-olahraga-pagi-bareng-wargadi-gbk-1rNLrnZCExS (Diakses pada: 29 November 2019).

Lee, M., Neely, G., dan Stewart, K. (eds.) (2012) The Practice of Government Public Relations. Boca Raton: Taylor and Francis.

Maksum, D. A. (2015) Tugas dan Fungsi Wakil Presiden di Indonesia, Lex Crimen, 4(1), hlm. 123-133.

Mardani (2018) 'Nimbrung' di gugatan masa jabatan wapres, JK dinilai ambisi kekuasaan. Merdeka. Dapat diakses di: https://www.merdeka.com/politik/nimb rung-di-gugatan-masa-jabatan-wapresjk-dinilai-ambisi-kekuasaan.html (Diakses pada: 4 Desember 2019). 
Moleong, L. J. (2014) Metodologi Penelitian Kualitatitf. Bandung: Remaja Rosdakarya.

Mulyadi, M. (2011) Penelitian Kuantitatif dan Kualitatif serta Pemikiran Dasar Menggabungkannya, Jurnal Studi Komunikasi dan Media, 15, hlm. 127137.

Nurjanah, A., Widyasari, W., dan Yulianti, F. (2015) Public Relations dan Media Relations: Kritik Budaya Amplop Pada Media Relations Institusi Pendidikan di Yogyakarta, Jurnal Komunikasi, hlm. 41-56.

Olga, S. (2014) Strategi Media Relations Ciputra World Surabaya dalam Special Event Halloweenation, Jurnal EKomunikasi, 2, hlm. 1-8.

Peraturan Menteri Negara Pemberdayaan Aparatur Negara (2007) Pedoman Umum Hubungan Masyarakat di Lingkungan Instansi Pemerintah. Jakarta.

Park, S., Bier, L. M., dan Palenchar, M. J. (2016) Framing a mystery: Information subsidies and media coverage of Malaysian airline flight 370, Public Relations Review, 42, hlm. 654-664.

Ponco, A. dan Khoiri, I. (2011) JK Tokoh Perdamaian Dunia. Kompas. Dapat diakses di: https://edukasi.kompas.com/read/2011/ 10/01/1245207/jk.tokoh.perdamaian.du nia (Diakses pada: 22 November 2019).

Prasetyo, K. (2016) Koalisi Dominan Humas DPR-RI sebagai Boundary Spanner dalam Mewujudkan Good Governance melalui Informasi Publik, Jurnal Media Kom, 6 (2), hlm 16-30.

Rachmiatie, A. dkk. (2013) Strategi Komunikasi Politik dan Budaya Transparansi Partai Politik, Mimbar Jurnal Sosial dan Pembangunan, 29 (2), hlm. 123-132.

Raharjo, R. S. (2015) Media Relations di Media Massa: Analisis Deskriptif Kualitatif terhadap Kegiatan Media Relations TVRI Yogyakarta dan Jogja
TV, Jurnal Profetik, 8 (2), hlm. 27-36.

Rahardjo, M. (2017) Studi kasus dalam penelitian kualitatif: konsep dan prosedurnya, Research Repositor Universitas Islam Negeri Maulana Malik Ibrahim, hlm. 1-26.

Rahman, A. (2018) Uji Materi Jabatan Wapres Langkah Mundur Regenerasi. Indo Pos. Dapat diakses di: https://indopos.co.id/read/2018/07/26/1 45399/uji-materi-jabatan-wapreslangkah-mundur-regenerasi/ (Diakses pada: 4 Desember 2019).

Rina, A. (2018) Juru Bicara Wapres Ungkap Alasan JK Ajukan Diri Jadi Pihak Terkait pada Uji Materi di MK. Tribunews. Dapat diakses di: https://www.tribunnews.com/nasional/ 2018/07/23/juru-bicara-wapresungkap-alasan-jk-ajukan-diri-jadipihak-terkait-pada-uji-materi-di-mk (Diakses pada 4 Desember 2019).

Rini, R. (2018) Jubir Wapres: Pak JK Tidak Berambisi Maju di Pilpres 2019. Tribunews. Dapat diakses di: https://www.tribunnews.com/nasional/ 2018/07/23/jubir-wapres-pak-jk-tidakberambisi-maju-di-2019 (Diakses pada: 4 Desember 2019).

Ristanto, T. (2014) Peran Humas Pemerintah Kota Balikpapan dalam Mengimplementasikan Konsep Smart City di Kota Balikpapan, Commonline Departemen Komunikasi, 4, hlm. 387399.

RMOL Sumsel (2019) Jelaskan Tanah Prabowo, JK Dipuji sebagai Negarawan. RMOL Sumsel. Dapat diakses http://www.rmolsumsel.com/read/2019 /02/20/110048/Jelaskan-TanahPrabowo,-JK-Dipuji-SebagaiNegarawan- (Diakses pada: 4 Desember 2019).

Sallot, L. M. dan Johnson, E. A. (2006) Investigating relationship between journalist and public relations practitioners: Working together to set, frame, and build the public agenda, 
Public Relations Review, 32, hlm. 151159.

Saputra, E., dkk. (2018) Rizal Mallarangeng Soal Gugatan JK Cawapres: Jangan Seperti Pak Harto. Kumparan. Dapat diakses di: https://kumparan.com/kumparannews/r izal-mallarangeng-soal-gugatan-jkcawapres-jangan-seperti-pak-harto27431110790550568 (Diakses pada: 4 Desember 2019).

Satriawan, Y. (2018) Jusuf Kalla Terima Penghargaan Perdamaian dan Kemanusiaan. VOA Indonesia. Dapat diakses di: https://www.voaindonesia.com/a/jusufkalla-trima-penghargaan-perdamaindan-kemanusiaan/4294761.html (Diakses pada: 22 November 2019).

Seitel, F. P. (2015) Praktik Public Relations. Jakarta: Erlangga.

Setyawan, F. A. (2016) Meliput di Lapangan Hingga Jadi Jubir Jusuf Kalla. Dapat diakses di: https://nasional.okezone.com/read/2016 /02/09/337/1307662/meliput-dilapangan-hingga-jadi-jubir-jusuf-kalla (diakses pada 10 September 2019).

Somantri, G. R. (2005) Memahami Metode Kualitatif, Makara Sosial Humaniora, 9 (2), hlm. 57-65.

Soemirat, S. dan Ardianto, E. (2017) Dasardasar Public Relations. Bandung: Remaja Rosdakarya.

Suaradotcom (2019) Wapres JK Dapat Kejutan Pengawalan F16 Milik TNI AU Jelang Purna Tugas.[Youtube] Dapat diakses di: https://www.youtube.com/watch?v=O MU8Kjs6NbY (Diakses pada 3 Desember 2019).

Sundoro, D. (2017) Wapres Jusuf Kalla Kunker ke Palangkaraya, Besok. RRI. Dapat diakses di:http://rri.co.id/post/berita/386259/na sional/wapres_jusuf_kalla_kunker_ke_ palangka_raya_besok.html (Diakses pada: 29 November 2019).
Suprawoto (2018) Government Public Relations: Perkembangan dan Praktik di Indonesia. Jakarta: Kencana.

Taylor, M. (2008) Protocol Journalism as a Framework for Understanding Public Relaitons Media Relationship in Kosovo. US: Elsevier.

Teresia, A. dan Riso, N. (2018) Jubir JK Soal Uji Materi di MK: Mustahil JK Gerak Tanpa Jokowi Tahu. Kumparan. Dapat diakses di: https://kumparan.com/kumparannews/j ubir-jk-soal-uji-materi-di-mk-mustahiljk-bergerak-tanpa-jokowi-tahu27431110790551670 (Diakses pada: 4 Desember 2019).

Towle, M. (1997) On behalf of the president: four factors affecting the success of the presidential press secretary, Presidential Studies Quaterly, 27 (2), hlm. 297-319.

Triyono, A. (2013) Strategi Media Relations Perguruan Tinggi di Surakarta, Jurnal Komuniti, 5, hlm. 1-9.

University of Twente (2019) Communication Theories. Netherlands. Dapat diakses dari: www.utwente.nl/communicationtheories (diakses pada 27 September 2019).

Viva (2018) Jubir JK Sebut Rizal Ramli Sedang Korslet. Vivanews. Dapat diakses di: https://www.viva.co.id/berita/politik/10 56500-jubir-jk-sebut-rizal-ramlisedang-korslet (Diakses pada: 29 November 2019)

Viva (2019) Fadli Zon Sebut JK Makin Negarawan dan Apa Adanya. Vivanews. Dapat diakses di:https://www.viva.co.id/berita/politik/ 1114494-fadli-zon-sebut-jk-makinnegarawan-dan-apa-adanya (Diakses pada: 4 Desember 2019).

WapresRI. (2017) Profil Pejabat. Dapat diakses di: http://www.wapresri.go.id/profilpejabat/ (diakses pada 13 September 2019). 